\title{
BUILDING TRUST IN A GUARANTEE FUND IN A CHALLENGING INSTITUTIONAL ENVIRONMENT
}

\section{ABSTRACT}

Difficult access to credit is a major obstacle to micro, small and medium-sized enterprises (MSMEs) survival, especially in emerging countries, affecting their competitiveness. Lack of guarantees is a main reason why banks do not lend to MSMEs. Guarantee schemes provide partial credit guarantees, but often fail to win trust of banks and enterprises. This study analyzes the process of building trust between the Fundo Garantidor para Investimentos (Investment Guarantee Fund, FGI), created in 2009, and banks in Brazil. This trust was hampered by the failure of public guarantee funds created in the 1990's. This created a challenging institutional environment to the new fund. The methodology employed was a case study, based on a qualitative approach with document analysis, semi-structured interviews and descriptive statistics. The analysis used models for building and repairing trust in inter-organizational relations and international benchmark for governance and effectiveness of guarantee schemes. The analysis showed that the FGI used other emerging countries and developed countries experience to construct adequate governance and succeeded in establishing trust with the banks. The results show that by 2017, 26 banks contract more than 32,000 operations worth 1.9 billion dollars, with additionalities comparable to the international benchmark.

Keywords: Inter-Organizational Trust; Credit Guarantee Schemes; Comparison of institutional Environments; Corporate Governance; Emerging Economies.

\section{CONSTRUINDO A CONFIANÇA DE UM FUNDO DE GARANTIA EM UM AMBIENTE INSTITUCIONAL DESAFIADOR}

\section{RESUMO}

A dificuldade no acesso ao crédito é um obstáculo importante para a sobrevivência das micro, pequenas e médias empresas (MPMEs), especialmente nos países emergentes, o que afeta sua competitividade. A falta de garantias é um dos principais motivos pelos quais os bancos não emprestam às MPMEs. Os sistemas de garantia oferecem garantias parciais de crédito, mas muitas vezes falham em obter a confiança dos bancos e empresas. Este estudo analisa o processo de criação de confiança entre o Fundo Garantidor para Investimentos (FGI), criado em 2009 e os bancos no Brasil. Esta confiança foi dificultada pelo fracasso dos fundos de garantia pública criados na década de 1990. Isso criou um ambiente institucional desafiador para o novo fundo. A metodologia utilizada foi um estudo de caso, baseado em uma abordagem qualitativa com análise de documentos, entrevistas semiestruturadas e estatística descritiva. A análise utilizou modelos para construir e reparar a confiança em relações interorganizacionais e as melhores práticas (benchmark) internacional para governança e eficácia de sistemas de garantia. A análise demostrou que o FGI usou a experiência de outros países emergentes e de países desenvolvidos para construir uma governança adequada e conseguiu estabelecer uma relação de confiança com os bancos. Os resultados mostram que, até 2017, 26 bancos contrataram mais de 32 mil operações no valor de 1,9 bilhões de dólares, com adicionalidade comparável ao benchmark internacional.

Palavras-chave: Confiança Interorganizacional, Sistemas de Garantia de Crédito; Comparação de Ambientes Institucionais; Governança Corporativa; Economias Emergentes. 


\section{CONSTRUYENDO LA CONFIANZA DE UN FONDO DE GARANTÍA EN UN MEDIO AMBIENTE INSTITUCIONAL DESAFIADOR}

\section{RESUMEN}

La dificultad en el acceso al crédito es un obstáculo importante para la supervivencia de las micro, pequeñas y medianas empresas (MPME), especialmente en los países emergentes, lo que afecta su competitividad. La falta de garantías es uno de los principales motivos por los que los bancos no prestan a las MPME. Los sistemas de garantía ofrecen garantías parciales de crédito, pero a menudo fallan en obtener la confianza de los bancos y las empresas. Este estudio analiza el proceso de creación de confianza entre el Fondo de Garantía para Inversiones (FGI), creado en 2009 y los bancos en Brasil. Esta confianza se vio dificultada por el fracaso de los fondos de garantía pública creados en la década de 1990. Esto creó un ambiente institucional desafiante para el nuevo fondo. La metodología utilizada fue un estudio de caso, basado en un abordaje cualitativo con análisis de documentos, entrevistas semiestructuradas y estadística descriptiva. El análisis utilizó modelos para construir y reparar la confianza en las relaciones interorganizacionales y las mejores prácticas internacionales para la gobernanza y la eficacia de los sistemas de garantía. El análisis demuestra que el FGI utilizó la experiencia de otros países emergentes y de países desarrollados para construir una gobernanza adecuada y logró establecer una relación de confianza con los bancos. Los resultados muestran que, hasta 2017, 26 bancos contrataron más de 32 mil operaciones por valor de 1.900 millones de dólares, con adicionalidad comparable al benchmark internacional.

Palabras clave: Confianza Interorganizacional, Sistemas de Garantía de Crédito; Comparación de Ambientes Institucionales; Gobierno corporativo; Economías Emergentes.

Luciano Quinto Lanz ${ }^{1}$ Patricia Amelia Tomei ${ }^{2}$

\footnotetext{
${ }^{1}$ Doutor em Administração de Empresas pela Pontifícia Universidade Católica do Rio de Janeiro - PUC/RJ. Brasil. Email: lqlanz@hotmail.com

${ }^{2}$ Doutora em Administração pela Universidade de São Paulo - USP. Professora da Pontifícia Universidade Católica do Rio de Janeiro - PUC/RJ. Brasil. E-mail: patomei@iag.puc-rio.br
} 


\section{INTRODUCTION}

Micro, Small and Medium-sized enterprises (MSMEs) has an important participation in Brazil's economy. MSMEs represent $98.5 \%$ of the private enterprises, $54 \%$ of formal employment (17.1 million people) and account for $27 \%$ of the GDP (Sebrae, 2017). In 2014, MSMEs with up to two years of existence had a mortality rate of $23.4 \%$ (Sebrae, 2016). Lack of credit, especially due to insufficient collateral, is one of the main reasons why firms shut down operations (Sebrae and Fubra, 2004). Guarantee funds constitute a public policy instrument designed to overcome the lack of guarantees, providing SMEs with access to credit by covering part of banks' credit risk in loans (Lopes et al, 2007).

During the world economic crisis and the lending contraction to firms, the Brazilian government created in 2009, new private guarantee funds for SMEs. Fundo Garantidor para Investimentos (Investment Guarantee Fund) - FGI, managed by the Banco Nacional de Desenvolvimento Econômico e Social (Brazilian Development Bank) BNDES was one of these funds. In April 2017, this fund had assets of R $\$ 909$ million (USD 286 million), with a $\mathrm{R} \$ 8,44$ billion (USD 2,6 billion) guaranteegranting potential (Bndes, 2017).

A guarantee fund success depends on trust between participants; this is influenced by its governance structure and the institutional environment. This article analyzes the process involved in repairing banks' trust in this type of guarantee, shaken by the failure of the FGPC Fundo de Garantia para a Promoção da Competitividade (Guarantee Fund for the Promotion of Competitiveness) created in 1997 and also managed by the BNDES. To achieve this goal the article analyzes FGI's governance structure and effectiveness using emerging and developed countries benchmark for guarantee funds and models of inter-organizational trust building and repair.

This study is justified by the important role played by guarantee schemes to foster financial inclusion, competitiveness and the expansion of MSME's participation in the economy. The analysis of the trust repair process may provide valuable insights to analyze other types of inter-organizational relationships, especially in environments characterized by institutional voids, economic change and turbulence, common in emerging countries.

The article is structured in five sections; this introduction; a review of the literature on competitiveness, guarantee schemes, interorganizational trust building and repair; the methodology used, results analysis; discussion of results and final considerations, with recommendations for future research.

\section{LITERATURE REVIEW}

The review of the literature includes credit and its influence over Brazil competitiveness and institutional environment; credit guarantee schemes (CGS), including the role of the National Development Banks (NDBs) in the credit guarantee system; CGS ownership (public or private) and governance structure, motivation and performance indicators; and inter-organizational trust building and repair.

\section{Competitiveness and Institutional Environment}

Competitiveness indexes are often used to evaluate and compare countries institutional environments. According to Lall (2001), a competitiveness index should fulfill two conditions: (i) it must "confine itself to activities that involve competition" between countries, not dealing with productivity or growth; and (ii) it should evaluate "market failures that affect competitive ability, especially the evolution of dynamic comparative advantage".

World Economic Forum Global Competitiveness Index (GCI), proposed by Schwab and Sala-i-Martin (2017), comprises 12 pillars, with 114 indicators, 80 from the executive survey and 34 from other sources. These other indicators are concentrated on macroeconomic environment, health and primary education and technological readiness. Infrastructure, higher education and training and financial market indicators rely mainly on the survey.

Lack of credit access is clearly a market failure. Many indicators from GCI can affect credit access and availability. Between these indicators is possible to identify items especially in 3 pillars: Institutions: irregular payments and bribes, judicial independence, efficiency of the legal framework in settling disputes, ethical behavior of firms, strength of auditing and report standards; Macroeconomic Environment: government budget balance, country credit rating; Financial market development: financing through local equity market, ease to access loans, venture capital availability, soundness of banks and legal rights index (Schwab, Sala-i-Martin, 2017).

\section{Credit Guarantee Schemes for MSMEs}

According to Beck and de la Torre (2007), the high costs of transactions and the intrinsic high-risk account for the reluctance of financial institutions to provide financing to MSMEs. To overcome these difficulties, many countries have created partial CGS (Beck et al, 2010). Beck et al (2008) reported that banks view CGS as the most common and effective program of government support for loans to MSMEs, 
ahead of directed credit and the use of interest rates of regulatory subsidies.

According to Honohan (2010), it is common for governments to become involved in guarantee systems to compensate for market flaws and attain social well-being by attempting to minimize the effect of the adverse selection and moral hazard on the rates charged from SMEs. Governments attempt to correct the uneven distribution of credit allocation which, under normal circumstances, does not reach poorer areas. They also seek to explore the externalities of the dynamism of entrepreneurs who lack resources, increase loans to SMEs and avoid or minimize credit crunches. One of the arguments used is that banks do not provide loans directly to SMEs because they lack guarantees and do not realize the risk that they run. Guarantee systems break this vicious circle. In addition to the issue of well-being, other issues encourage governments to use credit systems: (i) their similarity to private risk sharing systems; (ii) optimistic pricing and separate accounting from the public budget, which minimizes fiscal costs; and (iii) little need for capital allocation as the systems have leverage.

According to Beck et al. (2010), we can classify the systems in accordance with their ownership (public or private) and governance structure: credit guarantee companies, national public programs and private corporate associations.

According to Lanz and Perufo (2013), partial credit guarantee schemes can be classified into three types: guarantee funds (GF), guarantee programs (GP) and mutual guarantee associations (MGA). Table 1 shows the characteristics of each guarantee scheme.

Table 1 - Main characteristics of each guarantee scheme

\begin{tabular}{|c|c|c|c|c|}
\hline TYPE & NATURE & RESOURCES & OPERATION & LIQUIDITY \\
\hline $\begin{array}{l}\text { Guarantee } \\
\text { funds }\end{array}$ & $\begin{array}{l}\text { Public, private or } \\
\text { mixed }\end{array}$ & $\begin{array}{l}\text { Public and private } \\
\text { resources, seeking } \\
\text { to be self- } \\
\text { sustaining }\end{array}$ & $\begin{array}{l}\text { Operational activities } \\
\text { (analysis, concession and } \\
\text { recovery) delegated to } \\
\text { financial agents }\end{array}$ & $\begin{array}{l}\text { High (resources are } \\
\text { available in the } \\
\text { fund) }\end{array}$ \\
\hline $\begin{array}{l}\text { Guarantee } \\
\text { programs }\end{array}$ & $\begin{array}{l}\text { Public (operated by } \\
\text { state agency or } \\
\text { development bank) }\end{array}$ & $\begin{array}{l}\text { Resources limited } \\
\text { by the public } \\
\text { budget }\end{array}$ & $\begin{array}{l}\text { Own or delegated } \\
\text { operational activities (but } \\
\text { with subrogation) }\end{array}$ & $\begin{array}{l}\text { Low (subject to } \\
\text { supervision and } \\
\text { contingency of } \\
\text { resources) }\end{array}$ \\
\hline $\begin{array}{c}\text { Mutual } \\
\text { guarantee } \\
\text { associations }\end{array}$ & Private & $\begin{array}{l}\text { Private resources } \\
\text { from your } \\
\text { associates }\end{array}$ & $\begin{array}{l}\text { Own operational } \\
\text { activities: analysis, } \\
\text { concession and recovery }\end{array}$ & $\begin{array}{l}\text { Average (limited by } \\
\text { its regional scope) }\end{array}$ \\
\hline
\end{tabular}

Source: Adapted by the authors based on Pombo and Herrero (2003), Zica e Martins (2008) and OECD (2010).

According to Lanz and Tomei (2014) guarantee funds usually have greater liquidity, are more similar to private risk sharing systems, have more freedom to delegate operational activities to financial agents and seek to achieve financial sustainability. Guarantee funds have similar characteristics; however, they could be set up with different sources of resources, equity structures, governance structures, scope of coverage (beneficiaries types, limits), leverage and processes for claim and credit recovery. These characteristics usually are adapted to each country institutional and legal environment.

\section{CGS and institutional environment in Brazil}

According Chieza and Ambros (2006) a milestone in Brazil guarantee systems is the creation of public guarantee funds in 1996 as an alternative to improve SMEs credit access, providing guarantees to banks. However, the funds had limited scope of actuation because they were linked only to certain institutions operations as SEBRAE, with the Guarantee Fund of Small and Medium Enterprises [Fundo de Aval para Micro e Pequenas Empresas FAMPE], BNDES with the Guarantee Fund for the Promotion of Competitiveness [Fundo de Garantia para Promoção da Competividade - FGPC] and Banco do Brasil, with the Guaranty Fund for Employment and Income Generation [Fundo de Aval para a Geração de Emprego e Renda FUNPROGER]. Besides that, their structure, by its public nature, was closer to the guarantee program model, than a guarantee fund, as public budget dependent funds, with low liquidity.

According to Lanz and Macedo (2014), since 2009 guarantee funds have been structured in Brazil that seek to combine the best characteristics of 
governance from existing models, such as being of a private nature with assets segregated from those of the shareholders and administrator, with no counterguarantees from the government, and seeking to be self-sustainable.

\section{National Development Banks and Guarantees}

NDBs managed guarantee schemes in many countries. According to Torres and Zeidan (2016) there is a life-cycle for the existence of development banks. It comprises four phases: establishment, development, engine for growth and developed financial markets. Each phase has typical instruments. the instruments for earmarking credit have two categories: direct, the NDB autonomously originate debt or equity; and indirect origination, NDBs create incentives to stimulate other financial intermediaries to originate loans related to government targeted investment projects, companies or industrial sectors. These incentives can be divided into provision of long-term funds; guarantees; equalization; and penalties.

NDBs can provide guarantees for long term funds in either category: direct and indirect. The provision of guarantee to indirect operations or longterm operations using resources from the financial agents is common. Sometimes banks operate these instruments directly, sometimes through funds or related companies (Torres, Zeidan, 2016).

Guarantee support is consistent with Studart and Gallagher (2106) view of NDBs support to sustainable projects five fronts. Guarantee can help in project development and scaling up, leveraging finance, reduce the cost of capital to the borrower, crowding-in private capital, and improving governance and inclusiveness.

\section{Guarantee schemes effectiveness}

Guarantee schemes usually rely on public resources; therefore, it is important to verify the benefits of the system to society. According to Jonsson (2009), additionality is the main benefit and performance is evaluated based on the benefits for the three parties involved: the guarantor, the borrower and the lender.

Additionality refers to the impact of the system on the borrower and whether he would have access to the credit under better conditions or if the guarantee implies the receipt of higher values. The measurement of the performance of a guarantee system expressed by additionality is technically challenging. According to Saadani et al (2011) different indicators are used for this evaluation, like interviews with the SMEs beneficiaries to identity if the guarantee systems was determinant to credit access; use of descriptive statistics using other riskier borrowers as a proxy; propensity score matching (using control groups); regression discontinuity (control groups and credit scoring); randomized experiment (controlled rejections); natural and quasinatural experiment (alteration of eligible criteria, different banks, different periods of time and regions). According to Jonsson (2009), additionality can be labeled as financial and economic. Financial additionality indicates whether the SME would have access to financing in the absence of a guarantee. Economic additionality refers to the economic and social benefits, positive externalities such as the creation of jobs and expanded production.

According to Green (2003), an evaluation of the system from the viewpoint of the guarantor seeks to ensure maximum additionality in the long term. The indicators evaluate the cost-effectiveness and sustainability relationship. According to Jonsson (2009), sustainability is measured by the capacity of the guarantor to cover his costs, either through charges, direct subsidy, donations or income from the investment of resources in the fund. The percentage of financing in the country for SMEs with guarantees is an indicator of the global impact of the system. The degree of leverage is considered an indicator of the successful exploitation of the stabilizing resources of guarantees. Another important indicator is the default rate.

From the viewpoint of the borrower, the effectiveness of the system can be translated by indicators such as the number of loans and improved conditions, increased values and deadline and lower tax rates, reduced collateral and faster processing of loan applications (Jonsson, 2009; Green, 2003).

For the lender, the performance indicators are linked to behavior in relation to SMEs and the rate of coverage requests. Lanz and Tomei (2013) identified other indicators, such as the period of time between the application and payment of coverage and the rate of rejected coverage requests linked to the conformity of operations with the rules of the guarantee system, which should seek simplicity and clarity.

According to Lanz and Tomei (2014), the main benefits of this type of fund for the bank are the shared credit risk, the application of a favorable risk weighting factor to determine the regulatory capital required by the Central Bank, and the liquidity of collateral, which has no restraints on its trigger and depends only on default by the beneficiary, similar to a bank guarantee.

\section{Inter-Organizational Trust Building and Repair}

Trust is essential for the development of an effective relationship between organizations. Based on Mayer et al (1995) and Zaheer et al (1998), trust is accepting to be vulnerable to another party, based on the expectation that this party will fulfill his 
obligations, behave as expected, act and negotiate fairly, especially when an opportunity for opportunistic behavior appears.

According to Handley and Benton (2013), one of the main concerns in the management of interorganizational relationships is the behavioral or relational uncertainty that arises due to the misalignment of goals or incentives between the parties. Establishing trustworthy relations minimize the impacts of uncertainty and relational risk. It is important to align the behavior of the companies with the interests of the alliance.

High levels of interdependence create an environment that cultivates and perpetuates trust and commitment by making the costs of opportunistic behavior prohibitive for partners (Gulati, Sytch, 2007). The possibility of monitoring to determine if there are deviations from the standard or rules and institutional structures (safeguards) that allow standards and rules to be re-established, even in a coercive way help to minimize opportunistic behavior (Das, Teng, 2001).

According to Lewicki and Bunker (1995) repeated interaction and the creation of a relationship between parties create predictability, which is a source of trust. Becerra and Gupta (2003) identified that the frequency of communication has a similar role, the greater the frequency, the lower the receiver's perception of dependence on the person responsible for communication aimed at establishing a relationship of trust and greater the trust. Gulati and Sytch (2007) identified that the quality of the exchange of information between partners, in terms of details, accuracy and timeliness, influence interorganizational performance.

Faems et al. (2008) analyzed governance structures for inter-organizational relationships and identify two perspectives: structural and relational. The structural perspective focus analysis on single transactions, expects partners to behave opportunistically and use complex contracts to prevent this kind of behavior. This perspective is unsuited to long-term relations. The relational perspective, based on social exchange theory uses trust as a governance mechanism.

Malhotra and Murnighan (2002) investigated the effect of contracts on interpersonal trust and found evidence that the use of binding contracts, i.e. that can be enforced by applying penalties and the force of law have negative impacts on trust building. Non-binding contracts, on the other hand, lead to cooperation between parties and provide a basis for trust building.

Boehs and Segatto-Mendes (2007) identify some mechanisms used to create trust in joint ventures, such as establishing controls on entry (distribution of resources, information management) behavior (policies, rules, procedures, standardization) and exit (targets, budgets, results); socialization of values in order to define and create common values; personal involvement, in which the managers of partnerships pay visits, arrange meetings and make verbal communications; and the existence of specific hierarchical structures that emphasize and support partners.

According to Sundarämurthy and Lewis (2003), the context is important in determining the prevalence of control or collaboration/trust in governance. In a context of low performance control tends to be reinforced and lead to decline, whereas in a high-performance environment trust is reinforced which tends to enhance performance. The cycle of low performance can be broken with some measures: encourage trust in the abilities of others while recognizing cognitive limitations and conflicts so as to improve controls and build constructive debates; foster the diversity of ideas and heterogeneous backgrounds, in addition to creating shared understandings.

Tomlinson and Mayer (2009) present proposals for repairing trust: demonstrate that the breakdown of trust or the negative result was caused by an external agent and not the internal agent's inability or lack of benevolence or integrity. Repair is more effective if conflicts are reduced, diminishing anxiety and the fear that situations will repeat themselves, by apologizing, presenting justifications and demonstrating that the attributions of trust remain intact and that the new situation is stable.

Mesquita (2007) affirms that the rebuilding of trust between firms may require the services of a facilitator who has a reputation for trustworthiness, recognized leadership, mediation and negotiation skills. The process has a greater chance of success when (a) it takes place inside legitimate institutional environments, (b) is aimed at specific groups and tasks and (c) the conflicts involved have more to do with business matters than personal antipathy.

Gillespie and Dietz (2009) identify two components of trust repair interventions: curbing behaviors viewed as being untrustworthy and reinforcing/demonstrating trustworthy behaviors.

According to the literature, trust is essential for inter-organizational relationships and develops in the presence of information exchange, communication, relational structures with nonbinding contracts and long-term orientation. When trust is broken is important to repair the relationship to improve performance, and to do so is important to apologize, justify actions taken, and diminish potential conflicts by reinforcing trustworthiness' behavior.

The next section explains the methodology used in this case study, how the literature and 
international benchmark for guarantee schemes governance and effectiveness were applied to access FGI inter-organizational trust building.

\section{METHODOLOGY}

The methodology used combine a qualitative approach and use descriptive statistics, based on the mixed methods approach. proposed by Creswell (2013). This allows the triangulation of multiple sources of data and results from different methods, in order to overcome the limitations of each method alone, and contribute to theory. The FGI case study was performed with interviews and document analysis with fund manager team - the BNDES - in Rio de Janeiro, Brazil. For data collection purposes, ten interviews were undertaken with managers of the fund at the BNDES in order to gauge their perceptions regarding the themes examined in the theoretical references, using the interview script outlined in Table 2, between 2013 and 2016.

Table 2 - Interview Script

\begin{tabular}{|l|l|}
\hline \multicolumn{1}{|c|}{ QUESTION } & \multicolumn{1}{|c|}{ AIM OF THE QUESTION } \\
\hline $\begin{array}{l}\text { 1. Did FGI used any national or international benchmark } \\
\text { to set up its governance structure? Which one(s)? }\end{array}$ & $\begin{array}{l}\text { Identify national and international benchmarks } \\
\text { used to set up governance. }\end{array}$ \\
\hline $\begin{array}{l}\text { 2. What kind of governance structure does the FGI } \\
\text { have? What distinguishes it from the FGPC's structure? } \\
\text { Explain. }\end{array}$ & $\begin{array}{l}\text { Identify whether the structure uses the structural or } \\
\text { relational perspective (Faems et al. 2008) }\end{array}$ \\
\hline $\begin{array}{l}\text { 3. How does the FGI behave towards the financial } \\
\text { agents? How is the relationship between the parties? }\end{array}$ & $\begin{array}{l}\text { Identify managers' behavior / relationship between } \\
\text { FGI and financial agents (Lewicki and Bunker, } \\
\text { 1995): }\end{array}$ \\
\hline $\begin{array}{l}\text { 4. How would you define the FGI's reputation? And the } \\
\text { BNDES's? What has been done to generate trust in this } \\
\text { guarantee fund? }\end{array}$ & $\begin{array}{l}\text { Identify their view of the fund's reputation } \\
\text { (Tomlinson and Mayer, 2009). }\end{array}$ \\
\hline $\begin{array}{l}\text { 5. Describe the communication and information } \\
\text { exchange process between the FGI and banks. }\end{array}$ & $\begin{array}{l}\text { Identify the communication process and openness } \\
\text { degree between parties (Becerra and Gupta, 2003; } \\
\text { Gulati and Sytch, 2007). }\end{array}$ \\
\hline $\begin{array}{l}\text { 6. How is contract fulfillment formalized and verified? } \\
\text { Explain and give examples. }\end{array}$ & $\begin{array}{l}\text { Identify contract type: binding or non-binding } \\
\text { (Malhotra and Murnighan, 2002). }\end{array}$ \\
\hline $\begin{array}{l}\text { 7. How does the FGI's monitoring and control system } \\
\text { work? What are the main control mechanisms used? }\end{array}$ & $\begin{array}{l}\text { Identify what kind of controls the Fund uses } \\
\text { (Boehs and Segatto-Mendes, 2007). }\end{array}$ \\
\hline $\begin{array}{l}\text { 8. How are conflicts between banks and the FGI } \\
\text { resolved? Are their many conflicts? What type? }\end{array}$ & $\begin{array}{l}\text { Identify types and level of conflict (Mesquita, } \\
\text { 2007; Sundarämurthy and Lewis 2003). }\end{array}$ \\
\hline $\begin{array}{l}\text { 9. What are the main benefits provides by the Fund to } \\
\text { the Financial Agents and to the SMEs? }\end{array}$ & $\begin{array}{l}\text { Identify the main benefits provided by the Fund } \\
\text { (Lanz and Tomei, 2014; Jonsson, 2009, Green, } \\
\text { 2003). }\end{array}$ \\
\hline $\begin{array}{l}\text { 10. Describe the FGI's performance in financial terms, } \\
\text { number of customers (market share) and in terms of } \\
\text { banks' satisfaction? }\end{array}$ & $\begin{array}{l}\text { Identify performance perception (Faems et al. } \\
\text { 2008). }\end{array}$ \\
\hline
\end{tabular}

Source(s): Prepared by the Authors based on Lanz and Tomei (2016).

The subjects' selection criteria were convenience and accessibility. Interviews were conducted face to face, recorded and transcripted. Content analysis was used to extract respondents' perceptions about the topics covered. The managers interviewed have between 5 and 10 years of BNDES.
Their academic formations are economists, business, accountants and lawyers. Table 3 shows respondents responsibilities. Confidential data and information protected by law about the FGI were omitted from the final report. 
Table 3 - Interview Participants

\begin{tabular}{|c|c|l|}
\hline DIVISIONS & RESPONDENTS & \multicolumn{1}{|c|}{ ATTRIBUTIONS } \\
\hline $\begin{array}{c}\text { Department } \\
\text { Chief }\end{array}$ & 1 interview & Responsible for FGI and FGPC \\
\hline $\begin{array}{c}\text { Product and } \\
\text { Project }\end{array}$ & 3 interviews & $\begin{array}{l}\text { Development of new products. Adjustments to existing products } \\
\text { and standards. }\end{array}$ \\
\hline $\begin{array}{c}\text { Institutional } \\
\text { Relationship }\end{array}$ & 2 interviews & $\begin{array}{l}\text { Institutional relations, new financial agents' habilitation and } \\
\text { training of financial agents }\end{array}$ \\
\hline Operations & 2 interviews & $\begin{array}{l}\text { Operating activities: analyzing claims requests, processing } \\
\text { payments, credit recovery and operations auditing. }\end{array}$ \\
\hline Legal & 2 interviews & $\begin{array}{l}\text { Responsible for legal support to all divisions, contracts elaborations } \\
\text { and fund "by-laws". }\end{array}$ \\
\hline
\end{tabular}

Source(s): Prepared by the Authors.

Guarantee schemes structure and governance data collection relied on secondary data, especially information released by governments, multilateral institutions, development banks, guarantee funds, journals and theses about inequality and guarantee schemes for MSMEs. To evaluate the impact of the use of the FGI in terms of the feasibility of MSMEs gaining access to credit, several measurements were used to evaluate additionality, such as comparing success in gaining access to credit by companies with similar characteristics, with and without the guarantee of the FGI from the beginning of operations in 2010 until December 2016.

The limitations of the study include the fact that only SMEs that had undergone a credit analysis by the banks authorized to conduct indirect operations with the BNDES were included, representing a subset of SMEs. Besides that, there is no data related to job generation or revenue increase for the firms analyzed, which prevent the study to evaluate social and economic additionality. However, firms in poorer regions of the country having access to credit, firms with higher risk and other indicators can be used as a proxy for this analysis. As this is a single case study with qualitative analysis and a limited set of operations for analysis, due to the possible bias in the selection of subjects, the results cannot be used to make statistical generalizations. Generalizations can only be made of the theoretical propositions (Yin, 2013).

\section{RESULTS}

\section{Structure and governance analysis}

In order to identify the characteristics of guarantee schemes that could serve as models for FGI analysis, the experience of other countries was summarized in Table 4. The analysis demonstrates the national guarantee schemes usually are operated as public entity or have mixed control, between government and a public bank, the same occurs with the resources used (Mexico, Argentina and France). Guarantee coverage usually is above $50 \%$. Governance structure usually have audits, shareholders and supervisory authorities, in some cases using banking rules, that is also the main criteria for leverage (Basel rules). Claims usually require proof of judicial execution and in most cases, are delegated to the financial agents. Beneficiaries typically are MSMEs, with investment and working capital purposes. Guarantees are operated by loan, but in some cases, there is portfolio, mezzanine and second floor guarantees. 
Table 4 - Guarantee Schemes Characteristics from Selected Countries

\begin{tabular}{|c|c|c|c|c|c|c|c|}
\hline COUNTRY & CHILE & COLOMBIA & MEXICO & ARGENTINA & FRANCE & GERMANY & AUSTRIA \\
\hline Fund / Entity & $\begin{array}{l}\text { Fondo de Garantía } \\
\text { para Pequeños } \\
\text { Empresários } \\
\text { (FOGAPE) }\end{array}$ & $\begin{array}{l}\text { Fondo Nacional de } \\
\text { Garantias (FNG) }\end{array}$ & $\begin{array}{l}\text { Nacional } \\
\text { Financeira S. A. } \\
\text { (Nafinsa) }\end{array}$ & $\begin{array}{l}\text { Fondo de Garantía } \\
\text { para la Micro, Pequeña } \\
\text { y Mediana Empresa } \\
\text { (FOGAPyME) }\end{array}$ & $\begin{array}{l}\text { BPI - France / } \\
\text { former OSEO } \\
\text { (manages several } \\
\text { funds) }\end{array}$ & $\begin{array}{l}\text { Verband Deutscher } \\
\text { Bürgschafts-banken } \\
\text { (VDB) }\end{array}$ & $\begin{array}{c}\text { Austria } \\
\text { Wirtschaftservice } \\
\text { (AWS) }\end{array}$ \\
\hline Type of entity & Public & $\begin{array}{l}\text { Private (mixed } \\
\text { economy) }\end{array}$ & Public & Public & $\begin{array}{l}\text { Private (mixed } \\
\text { economy) }\end{array}$ & $\begin{array}{l}\text { Private (Registered } \\
\text { association) }\end{array}$ & Public (state owned) \\
\hline Resources & $\begin{array}{l}\text { Government } \\
\text { contributions, } \\
\text { guarantee fees, } \\
\text { return over } \\
\text { investments and } \\
\text { claims recovery. }\end{array}$ & $\begin{array}{l}\text { Government } \\
\text { contributions, } \\
\text { guarantee fees, } \\
\text { return over } \\
\text { investments and } \\
\text { claims recovery. }\end{array}$ & $\begin{array}{l}\text { Government } \\
\text { contributions, } \\
\text { guarantee fees, } \\
\text { return over } \\
\text { investments and } \\
\text { claims recovery. }\end{array}$ & $\begin{array}{l}\text { Banco de la Nación } \\
\text { Argentina, Secretaría } \\
\text { de Hacienda and } \\
\text { Banco de Inversión y } \\
\text { Comercio Exterior }\end{array}$ & $\begin{array}{l}\text { Government } \\
\text { contributions, } \\
\text { guarantee fees, } \\
\text { return over } \\
\text { investments and } \\
\text { claims recovery. }\end{array}$ & $\begin{array}{l}17 \text { guarantee banks. } \\
\text { Counter-guarantee } \\
\text { from Federal } \\
\text { Republic of } \\
\text { Germany and } \\
\text { Federal States }\end{array}$ & Government \\
\hline $\begin{array}{l}\text { Equity } \\
\text { structure }\end{array}$ & $\begin{array}{l}\text { Banco Estado is the } \\
\text { only shareholder }\end{array}$ & $\begin{array}{l}\text { Government (Min. } \\
\text { Hacienda, Min. } \\
\text { Comercio), Banks } \\
\text { and Funds } \\
\text { (Bancóldex, } \\
\text { Findeter) }\end{array}$ & $\begin{array}{l}\text { Mexican } \\
\text { Government }\end{array}$ & $\begin{array}{l}\text { Argentinian } \\
\text { Government }\end{array}$ & $\begin{array}{l}\text { French } \\
\text { Government (50\%) } \\
\text { and Caisse des } \\
\text { dépôts et } \\
\text { consignations - } \\
\text { CDC (50\%) }\end{array}$ & $\begin{array}{l}100 \% \text { private. } \\
\text { Legally and } \\
\text { economically } \\
\text { independent } \\
\text { Guarantee Banks in } \\
\text { each federal state } \\
\text { (Bundesland) }\end{array}$ & $\begin{array}{l}\text { Limited Company - } \\
\text { Financial Institution }\end{array}$ \\
\hline $\begin{array}{l}\text { Management } \\
\text { fee }\end{array}$ & $\begin{array}{l}0.15 \% \text { of the } \\
\text { formalized } \\
\text { guarantees and } 10 \% \\
\text { of the profit for the } \\
\text { year }\end{array}$ & N/A & N/A & N/A & N/A & $\begin{array}{l}\text { Administrative fees } \\
\text { (Variable amount } \\
\text { according to nominal } \\
\text { amount of the } \\
\text { guarantee } \\
\text { commitment) }\end{array}$ & N/A \\
\hline $\begin{array}{l}\text { Governance } \\
\text { structure }\end{array}$ & $\begin{array}{l}\text { Administrator, } \\
\text { Audit, Banking } \\
\text { Supervision and } \\
\text { Ministry of Finance }\end{array}$ & $\begin{array}{l}\text { Administrators, } \\
\text { Shareholders' } \\
\text { Meeting, Audit, } \\
\text { AMV, Banking } \\
\text { Supervision, } \\
\text { Controllership. }\end{array}$ & $\begin{array}{l}\text { Committees for } \\
\text { Credit, Risk, } \\
\text { Audit, Internal } \\
\text { Control, Audit of } \\
\text { the Federal } \\
\text { Government }\end{array}$ & $\begin{array}{l}\text { Management } \\
\text { committee composed } \\
\text { of (state) shareholders. } \\
\text { Government }\end{array}$ & $\begin{array}{l}\text { Bank (merger of } \\
\text { OSEO with BPI). }\end{array}$ & $\begin{array}{l}\text { Bank. Specific } \\
\text { banking license } \\
\text { limited to guarantee } \\
\text { activities }\end{array}$ & Financial Institution \\
\hline Resources & Fixed income fund, & Fixed income & Fixed income & Fixed income & Variable and fixed & N/A & N/A \\
\hline
\end{tabular}


Building Trust in a Guarantee Fund in a Challenging Institutional Environment

\begin{tabular}{|c|c|c|c|c|c|c|c|}
\hline $\begin{array}{l}\text { management / } \\
\text { application }\end{array}$ & $\begin{array}{l}\text { in financial } \\
\text { instruments } \\
\text { authorized by the } \\
\text { Central Bank }\end{array}$ & $\begin{array}{l}\text { (government } \\
\text { bonds) }\end{array}$ & $\begin{array}{l}\text { (bonds, bonus e } \\
\text { certificates) }\end{array}$ & (government bonds) & income & & \\
\hline $\begin{array}{l}\text { Scope of } \\
\text { coverage }\end{array}$ & $\begin{array}{l}\text { Credit of the } \\
\text { financial agents } \\
\text { themselves. }\end{array}$ & $\begin{array}{l}\text { Credit of the } \\
\text { financial agents } \\
\text { themselves. }\end{array}$ & $\begin{array}{l}\text { Credit of the } \\
\text { financial agents } \\
\text { themselves. }\end{array}$ & $\begin{array}{l}\text { Credit of the financial } \\
\text { agents themselves. }\end{array}$ & $\begin{array}{l}\text { Credit of the } \\
\text { financial agents } \\
\text { themselves. }\end{array}$ & $\begin{array}{l}\text { VDB covers the } \\
\text { national level } \\
\text { whereas each } \\
\text { Guarantee Bank } \\
\text { covers only its } \\
\text { federal state }\end{array}$ & $\begin{array}{l}\text { National (Central } \\
\text { Scheme only) }\end{array}$ \\
\hline $\begin{array}{l}\text { Purpose of } \\
\text { guarantee } \\
\text { operations }\end{array}$ & $\begin{array}{l}\text { Investment and } \\
\text { working capital }\end{array}$ & $\begin{array}{l}\text { Investment, } \\
\text { working capital } \\
\text { and revolving } \\
\text { credit }\end{array}$ & $\begin{array}{l}\text { Investment and } \\
\text { working capital. }\end{array}$ & $\begin{array}{l}\text { Investment and } \\
\text { working capital. } \\
\text { Second tier MGAs. }\end{array}$ & $\begin{array}{l}\text { Investment, } \\
\text { working capital } \\
\text { and start-ups }\end{array}$ & $\begin{array}{l}\text { Agriculture, } \\
\text { Industry, Crafts, } \\
\text { Retail, Liberal } \\
\text { professions, } \\
\text { Cooperatives }\end{array}$ & $\begin{array}{l}\text { All sectors (with the } \\
\text { exception of } \\
\text { Agriculture and } \\
\text { Tourism) }\end{array}$ \\
\hline Beneficiaries & $\begin{array}{l}\text { MSME (Micro, } \\
\text { small and medium } \\
\text { enterprises) }\end{array}$ & $\begin{array}{l}\text { MSME and } \\
\text { housing of social } \\
\text { interest }\end{array}$ & $\begin{array}{l}\text { MSME, productive } \\
\text { chains and } \\
\text { microcredit. }\end{array}$ & MSME & MSME & $\begin{array}{l}\text { SMEs, Micro- } \\
\text { enterprises, } \\
\text { Independent/Self- } \\
\text { employed }\end{array}$ & Mainly SMEs \\
\hline $\begin{array}{l}\text { Type of } \\
\text { guarantee }\end{array}$ & Operation/loan & $\begin{array}{l}\text { Operation/loan } \\
\text { (limits by } \\
\text { borrower, financial } \\
\text { agent and credit } \\
\text { line) }\end{array}$ & $\begin{array}{l}\text { Operation /loan. } \\
\text { Portfolio, and first } \\
\text { losses (reverse } \\
\text { auction) }\end{array}$ & $\begin{array}{l}\text { Operation/loan. For } \\
\text { MGAs by portfolio }\end{array}$ & $\begin{array}{l}\text { Operation/ loan. } \\
\text { Mezzanine } \\
\text { financing } \\
\text { guarantees, }\end{array}$ & $\begin{array}{l}\text { Loan default } \\
\text { guarantees, } \\
\text { Mezzanine financing } \\
\text { guarantees, Leasing } \\
\text { guarantees and } \\
\text { specialized programs } \\
\text { for energy } \\
\text { contracting and } \\
\text { agriculture } \\
\text { guarantees }\end{array}$ & $\begin{array}{c}\text { Loan default } \\
\text { guarantees, Leasing } \\
\text { guarantees, Working } \\
\text { capital loan } \\
\text { guarantees, Project } \\
\text { guarantees and } \\
\text { Mezzanine financing } \\
\text { guarantees }\end{array}$ \\
\hline $\begin{array}{l}\text { Guarantee } \\
\text { Coverage / } \\
\text { Limits by } \\
\text { Beneficiary }\end{array}$ & $\begin{array}{l}\text { Up to } 80 \% \text { for Micro } \\
\text { and small enterprises } \\
\text { and export } \\
\text { companies; } 50 \% \\
\text { Mediums enterprises } \\
\text { e 30\% large } \\
\text { enterprises }\end{array}$ & Up to $50 \%$ & $\begin{array}{l}\text { Up to } 85 \% \text { for } \\
\text { start-ups, e } 70 \% \\
\text { for MSMEs. }\end{array}$ & $\begin{array}{l}\text { Up to } 65 \% \text { for } \\
\text { MSMEs. Up to } 40 \% \\
\text { for MGAs. Average } \\
\text { coverage is } 25 \% \text { for } \\
\text { MSMEs }\end{array}$ & $\begin{array}{l}\text { Up to } 70 \% \text {. Most } \\
\text { cases below } 50 \%\end{array}$ & $\begin{array}{l}\text { Up to } 90 \% \text { (SMEs } \\
\text { and stat-ups) } \\
€ 2 \text { million }\end{array}$ & Up to $80 \%$ to SMEs \\
\hline
\end{tabular}


Building Trust in a Guarantee Fund in a Challenging Institutional Environment

\begin{tabular}{|c|c|c|c|c|c|c|c|}
\hline $\begin{array}{l}\text { Stop loss } \\
\text { mechanism }\end{array}$ & No & No & No & $25 \%$ & $\begin{array}{l}\text { No, except new } \\
\text { funds w/o credit } \\
\text { history. }\end{array}$ & No & No \\
\hline Leverage limit & 10 times & $\begin{array}{l}\text { Basel Rules (11\% } \\
\text { solvency index) }\end{array}$ & Solvency margin & Total guarantees & Solvency margin & $\begin{array}{l}\text { Basel rules (solvency } \\
\text { margin) }\end{array}$ & $\begin{array}{c}\text { Basel rules (solvency } \\
\text { margin) }\end{array}$ \\
\hline Claim & $\begin{array}{l}\text { Proof of judicial } \\
\text { execution }\end{array}$ & $\begin{array}{l}\text { Proof of } \\
\text { extrajudicial or } \\
\text { judicial execution }\end{array}$ & $\begin{array}{l}\text { Proof of } \\
\text { extrajudicial or } \\
\text { judicial execution }\end{array}$ & $\begin{array}{l}\text { Proof of extrajudicial } \\
\text { execution }\end{array}$ & $\begin{array}{l}\text { After the } \\
\text { conclusion of } \\
\text { judicial execution }\end{array}$ & $\begin{array}{l}\text { N/A (each bank } \\
\text { associated) }\end{array}$ & N/A \\
\hline $\begin{array}{c}\text { Credit } \\
\text { recovery } \\
\text { responsible } \\
\end{array}$ & Financial Agent & $\begin{array}{l}\text { Own and delegated } \\
\text { to the Financial } \\
\text { Agent }\end{array}$ & Financial agent & $\begin{array}{l}\text { Financial agent or } \\
\text { MGA. }\end{array}$ & Financial Agent & $\begin{array}{l}\text { N/A (each bank } \\
\text { associated) }\end{array}$ & N/A \\
\hline $\begin{array}{l}\text { Financial } \\
\text { agents' } \\
\text { habilitation }\end{array}$ & $\begin{array}{l}\text { There is not. (Banks, } \\
\text { factoring, } \\
\text { cooperatives and } \\
\text { guarantee } \\
\text { associations). }\end{array}$ & $\begin{array}{l}\text { Simplified for } \\
\text { financial system } \\
\text { entities, complex } \\
\text { for cooperatives, } \\
\text { associations and } \\
\text { foundations. }\end{array}$ & $\begin{array}{l}\text { Assessment of } \\
\text { analysis, } \\
\text { evaluation, } \\
\text { monitoring and } \\
\text { recovery policies. }\end{array}$ & $\begin{array}{l}\text { Contract of } \\
\text { Qualification of the } \\
\text { agent or MGA. }\end{array}$ & $\begin{array}{l}\text { Evaluation analysis } \\
\text { and recovery of } \\
\text { credit. }\end{array}$ & $\begin{array}{l}\text { Terms and } \\
\text { conditions }\end{array}$ & N/A \\
\hline
\end{tabular}

Source: Prepared by the authors from the Ibero-American Forum of Guarantees, 2016; FNG, 2017, FOGAPYME, 2017, FOGAPE, 2017; NAFINSA, 2017; BPIFRANCE, 2017. AECM, 2017. 
The FGI structured is compatible with this benchmark and try to correct the deficiencies of the FGPC, which it replaced, as demonstrated in Table 5, constructed based on the analysis of the fund's by-laws, regulations and manuals. The comparison also relates the Fund's characteristics with the items from the literature review and GCI when applicable.

Table 5 - Characteristics of FGI - Fundo Garantidor para Investimentos versus FGPC - Fundo Garantidor para promoção da Competitividade

\begin{tabular}{|c|c|c|c|}
\hline Scope & FGPC & $F G I$ & $\begin{array}{l}\text { Mechanism of trust building } \\
\text { (Theoretical reference) }\end{array}$ \\
\hline Type of entity & Public & Private & \multirow{3}{*}{$\begin{array}{l}\text { The FGI is a joint venture with } \\
\text { interdependence between the parties (Gulati } \\
\text { and Sytch, 2007) which promotes the } \\
\text { alignment of participants' interests. This } \\
\text { institutional setting mitigates opportunistic } \\
\text { behavior and favors dispute settling. } \\
\text { (Handley and Benton, 2013) }\end{array}$} \\
\hline Resources & $\begin{array}{l}\text { Public budget. } \\
\text { Subject to budget } \\
\text { constraints. }\end{array}$ & $\begin{array}{l}\text { ABGF, BNDES, financial } \\
\text { agents. Segregated in fund. }\end{array}$ & \\
\hline $\begin{array}{l}\text { Equity } \\
\text { Structure }\end{array}$ & $\begin{array}{l}\text { Federal Government } \\
\text { as shareholder }\end{array}$ & $\begin{array}{l}\text { Public (ABGF and } \\
\text { BNDES) and private } \\
\text { shareholders (banks) }\end{array}$ & \\
\hline $\begin{array}{l}\text { Management } \\
\text { fee (BNDES) }\end{array}$ & N/A & $\begin{array}{l}0.15 \% \text { p.y. on managed } \\
\text { funds }+1 \% \text { p.y. On the } \\
\text { total assets (contracting } \\
\text { services directly paid by } \\
\text { the IGF) }\end{array}$ & $\begin{array}{l}\text { Clear limitation of costs, consistent with the } \\
\text { structural perspective of alliances and the } \\
\text { theory of transaction costs (Faems et al., } \\
\text { 2008). }\end{array}$ \\
\hline $\begin{array}{l}\text { Governance } \\
\text { Structure }\end{array}$ & $\begin{array}{l}\text { Administrator and } \\
\text { Audits }\end{array}$ & $\begin{array}{l}\text { Shareholders' Assembly, } \\
\text { Federal participation } \\
\text { Council, Administrator e } \\
\text { Audit, actuarial } \\
\text { Consulting. }\end{array}$ & \multirow{2}{*}{$\begin{array}{l}\text { The FGI has an institutional structure with } \\
\text { greater possibility of monitoring. } \\
\text { Ease of understanding the administration of } \\
\text { resources and evolution of results. It strength } \\
\text { the auditing and report processes. (Das and } \\
\text { Teng, 2001) }\end{array}$} \\
\hline $\begin{array}{l}\text { Resource } \\
\text { Management / } \\
\text { application }\end{array}$ & $\begin{array}{c}\text { Annual Federal } \\
\text { budget }\end{array}$ & $\begin{array}{l}\text { Active with fixed and } \\
\text { variable income, having as } \\
\text { benchmark IRF-M and } \\
\text { Ibovespa }\end{array}$ & \\
\hline $\begin{array}{l}\text { Scope of } \\
\text { coverage }\end{array}$ & $\begin{array}{l}\text { Operations with } \\
\text { BNDES resources }\end{array}$ & $\begin{array}{l}\text { Operations with BNDES } \\
\text { resources and credit from } \\
\text { financial institutions } \\
\text { themselves }\end{array}$ & \multirow{3}{*}{$\begin{array}{l}\text { Possibility of securing credit from the } \\
\text { institutions themselves, with a long-term } \\
\text { perspective and an expectation of expanding } \\
\text { the relationship. (Lewicki and Bunker, 1995; } \\
\text { Faems et al, 2008) }\end{array}$} \\
\hline $\begin{array}{l}\text { Purpose of } \\
\text { guarantee } \\
\text { operations }\end{array}$ & $\begin{array}{l}\text { Investment, working } \\
\text { capital e exports }\end{array}$ & $\begin{array}{l}\text { Investment, innovation and } \\
\text { working capital }\end{array}$ & \\
\hline Beneficiaries & $\begin{array}{l}\text { Micro and Small } \\
\text { Enterprises, besides } \\
\text { the Medium } \\
\text { Exporting Companies } \\
\text { or the Export Chain }\end{array}$ & $\begin{array}{l}\text { Micro, Small and Medium } \\
\text { Enterprises; Self-employed } \\
\text { Freight Carrier; Individual } \\
\text { Microentrepreneur }\end{array}$ & \\
\hline $\begin{array}{l}\text { Type of } \\
\text { guarantee }\end{array}$ & By operation/loan & $\begin{array}{l}\text { Per transaction (linked to } \\
\text { the stop loss rule in the } \\
\text { Agent's portfolio); By } \\
\text { portfolio; Indirect } \\
\text { guarantee as a second floor } \\
\text { to Credit Guarantee } \\
\text { Companies and FIDCs. }\end{array}$ & \multirow{2}{*}{$\begin{array}{l}\text { FGI has greater safeguards and limiters. } \\
\text { The form of guarantee, limits and stop loss } \\
\text { have the effect of generating greater } \\
\text { confidence in limiting losses and concern } \\
\text { with opportunism providing structural } \\
\text { security (Gulati and Sytch, 2007; Das and } \\
\text { Teng, 2001). } \\
\text { Theory of transaction costs. (Faems et al, } \\
\text { 2008) }\end{array}$} \\
\hline $\begin{array}{l}\text { Guarantee } \\
\text { Coverage / } \\
\text { Limits by } \\
\text { Beneficiary }\end{array}$ & Up to $80 \%$ & $\begin{array}{l}\text { From } 20 \% \text { to } 80 \% \text { of the } \\
\text { loan. Guarantee limited to } \\
\text { R } \$ 10 \text { million }\end{array}$ & \\
\hline
\end{tabular}




\begin{tabular}{|c|c|c|c|}
\hline $\begin{array}{c}\text { Stop loss } \\
\text { mechanism }\end{array}$ & N/A & $7 \%$ each 5 years' period & \\
\hline Leverage limit & 8 times the capital & 12 times the capital & \\
\hline $\begin{array}{l}\text { Claims } \\
\text { payment }\end{array}$ & $\begin{array}{l}\text { Subject to } \\
\text { Government budget } \\
\text { fiscal constraints. } \\
\text { Default rate } \\
\text { methodology based } \\
\text { on debit balance }\end{array}$ & $\begin{array}{l}\text { On first demand. Default } \\
\text { rate methodology based on } \\
\text { the net loss of the portfolio } \\
\text { ((Honored - Recovered } \\
\text { Value) / Guaranteed) }\end{array}$ & $\begin{array}{l}\text { Payment on first demand mitigates the } \\
\text { inefficiency of Brazil legal system (Schwab } \\
\text { and Sala-i-Martin, 2017). }\end{array}$ \\
\hline $\begin{array}{l}\text { Credit } \\
\text { recovery } \\
\text { responsible }\end{array}$ & $\begin{array}{l}\text { Restriction restricted } \\
\text { to rules or approval } \\
\text { by the Board in each } \\
\text { agreement. }\end{array}$ & $\begin{array}{l}\text { Pre-approved policy with } \\
\text { recovery delegated to the } \\
\text { Agent and subject to audit. }\end{array}$ & $\begin{array}{l}\text { Behavioral control (Boehs and Segatto- } \\
\text { Mendes, 2007). }\end{array}$ \\
\hline $\begin{array}{c}\text { Financial } \\
\text { agents' } \\
\text { habilitation / } \\
\text { qualification }\end{array}$ & $\begin{array}{l}\text { Qualification linked } \\
\text { only to the possibility } \\
\text { of operating with } \\
\text { BNDES. }\end{array}$ & $\begin{array}{l}\text { Contract with FGI subject } \\
\text { to quota contributions and } \\
\text { approval of the Credit } \\
\text { Recovery Policy. }\end{array}$ & $\begin{array}{l}\text { Input control, from a structural perspective } \\
\text { (Boehs e Segatto-Mendes, 2007). Better } \\
\text { information exchange (Gulati and Sytch, } \\
\text { 2007), higher frequency of communication } \\
\text { (Becerra e Gupta, 2003). }\end{array}$ \\
\hline
\end{tabular}

Source: Prepared by the authors based on BNDES information.

The fund has private nature, aimed at MSMEs and individuals (individual micro entrepreneurs and freight carriers), is not subject to budgetary constraints and has more flexible rules and processes, which are more agile and appropriate to the dynamics of its segment.

BNDES acting as manager of FGI is consistent with its role as a NDB, helping to expand credit access with better conditions, considering both indirect operations (with BNDES resources) operated by the banks as financial agents and providing guarantee to financial agents own funded operation for investments, innovation and working capital. It fosters project development and scaling up, leveraging finance, reduces the cost of capital to the borrower, crowding-in private capital, and improving governance and inclusiveness. FGI setting tries to compensate for credit market failures, helping to improve Brazil competitiveness.

\section{Interviews}

The interviews analysis indicated that the FGI's governance structure considered that international and national benchmark for guarantee schemes.

BNDES has participated for several years in SME guarantees' international forums, such as the IberoAmerican Forum of Guarantees. In addition, in the fund restructuring process, international experience was analyzed, with visits to OSEO (now BPI) in France, FNG in Colombia and Nafinsa in Mexico.

We held a discussion group with Banco do Brasil, manager of FGO, and Sebrae, manager of Fampe, to discuss the evolution of guarantee funds for MSMEs in Brazil. The exchange of experiences on accounting provision, credit recovery and regulatory affairs has been very rich.

... One of the discussions subjects with Banco do Brasil and Sebrae is the operation of the FGI as a second floor fund to work together with mutual guarantee associations, whose creation has been stimulated by Sebrae, based on the Italian experience.

The Fund tried to correct the flaws identified in the FGPC, such as its public nature, which led to budget constraints and delays in payments and its rigid credit recovery rules. To repair banks' trust in the guarantee, the governance initially emphasized the structural perspective, reinforcing trustworthy behavior, as proposed by Gillespie and Dietz's (2009), since, despite its private legal nature, most of the fund's assets were composed of public resources. This was accompanied by dissemination of information about the fund to possible operators and an attempt to start building a relationship with partner banks, in a perspective consistent with Faems et al. (2008) relational approach:

Trust in the FGI has improved, especially because at the beginning the FGI was seen as potentially a new FGPC... But the FGI gradually gained credibility and its operation was quite different from the FGPC's. Guarantee claims are always paid promptly...the banks' requests for changes are being accepted more frequently ...because, as it is a private fund, the FGI's rules can be altered more easily than if it were a public fund. 
The FGI's governance structure sought to correct the deficiencies identified in $B N D E S$ 's previous experience with guarantee funds. The FGI was structured as a private entity and is therefore not subject to budgetary constraints.

As proposed by Lewicki and Bunker (1995), the interviewees show that FGI tries to behave consistently and predictably, broadening its relationships:

I believe that they see us as being committed interlocutors but I also think that they realize that we won't be able to do everything and I think we usually emphasize this point during our visits to banks.

FGI...seek to meet the deadlines informed to the banks...

...the direction of changes is clear to the banks...

The FGI tried to build a reputation for credibility to repair trust, distinguish itself from the FGPC by. Following Tomlinson and Mayer's (2009) proposals, decisions are justified and partners are told when they depend on external agents, in accordance with.

In various cases, it is not possible to comply with banks' requests due to legal restrictions or because they conflict with the guidelines adopted by the government which is the fund's biggest investor. In these cases, the reasons for the decision are communicated to the requesting party.

Banks' demands are assessed and prioritized. When these demands are made by more than one bank, they tend to be implemented. In some cases, they require approval by the general meeting of fund shareholders which congregates all the banks who participate in the FGI.

As proposed by Becerra and Gupta (2003), managers explicitly recognize the role of the frequency of communication. Information sharing is used to create trust, with prior discussions of proposals for changes to rules. There is a concern to keep channels of communication that provide accurate, complete and timely information open, as proposed by Gulati and Sytch (2007).

Since its creation the fund has always listened to the banks. [...] Banks are informed in advance about changes to rules, systems and processes to enable them to adapt their internal systems, given that the FGI's processes, especially after guarantee hiring, are IT intensive.

The banks receive information regarding the value and performance of their shares in the fund on a monthly basis.

Changes are discussed and banks are informed about them in advance.

In line with the approach proposed by Zaheer et al (1998) and Malhotra and Murnighan (2002), a change was also identified in the nature of the rules governing contracts with banks, seeking to make them less binding and based more on cooperation between parties,

I think that the application of rules used to be more rigid but has become more flexible...

During the course of the operation the penalties laid down in the rules were attenuated and an adjustment of conduct provision was created to deal with cases where a financial agent has behaved in a way that is inappropriate or even contrary to some rule of the fund, but acted in good faith. These provisions stipulate that the agent must adjust his operation and may provide for some penalty, but this penalty is negotiated and is usually more lenient than the one foreseen by the general rule.

I think that the fund's contracts and rules used to have a negative effect on agents' perceptions, but this has changed. Now every time we change the statute and the rules we try to simplify processes in order to align them with agents' usual practices. I believe that agents' trust in FGI is increasing day by day.

The use of some mechanisms described by Boehs and Segatto-Mendes (2007) can be identified, such as standardization of operations with rules and procedures similar to those adopted by banks; socialization of values, through training programs and seminars; and personal involvement and a specific hierarchical structure, with the creation of an Institutional Relationship Department responsible for contacts and assessment of banks' procedures:

...The BNDES has sought to simplify processes to make them more compatible with banks' business routines.

... Procedures were examined together with the banks to identify any doubts they 
might have regarding the fund guarantee application process. Various doubts were indeed identified, thus leading to improvements in rules and enabling banks to fix problems before submitting guarantee claims to the fund.

We created a department that deals exclusively with the fund's relationship with banks. It is responsible for capturing new banks as shareholders, organizing training programs and publicizing the fund.

The interviews identified a low level of conflict and disputes between parties. Conflicts are mostly functional (Mesquita, 2007) and their solution often leads to improvements in performance, with collaboration prevailing over control and thus breaking the negative cycle identified by Sundarämurthy and Lewis (2003).

In general, that have been very few conflicts and when they occur they are resolved in a friendly fashion.

We have practically no conflicts with banks ...the treatment of cases outside the parameters or in which interpretations diverge have improved. The BNDES has made a greater effort to meet banks' requests.

[...] the level of conflict is low [...] when conflicts arise it is because a bank has not complied with a certain point of the rules and then a negotiation process begins.

The main benefits from the fund mentioned by the management team confirm the guarantee schemes literature (Lanz, Tomei, 2014; Jonsson, 2009; Green, 2003).

The financial agent earns liquidity in the guarantee, which allows him to accept good transactions that he would not normally contract due to insufficient collateral.

[...] The financial agent has the benefit of less need for capital allocation when using a guarantee fund. The effect is the same as a mortgage, but the execution of the guarantee is much faster.

[...] Qualified agents can offer financing to more customers, increase credit limits and can gain market share with the fund's guarantee.

The clients of the fund are the financial agents, they have to "buy the idea" of the fund and see value in the guarantee offered.
The benefit to MSME is access to credit. [...] the share of firms and individuals who had never had access to the BNDES's credit lines, is over 50\% of total beneficiaries, which shows that the fund is achieving its aim of increasing credit access.

The managers provided some examples of the effects of the governance structure on FGI's performance, highlighting qualitative aspects, that can be linked to trust building and long-term relationship perspective (Faems et al, 2008):

The fund's performance has improved significantly in qualitative terms... [...] in regional terms, the North and Northeast regions' share in the fund's operations is higher than the BNDES's overall average, showing that the fund is helping to de-concentrate operations to Brazil's less developed regions.

[...] The fund [...] has been successful in convincing a great number of banks to become shareholders. FGI is the guarantee fund with the greatest number of financial agents in Brazil.

[...] FGI currently have 26 financial agents as shareholders [...]

The Fund's market share in eligible operations for the fund's guarantee passed the international benchmark of $10 \%$ for this type of instrument.

Analyzing the interviews content is possible to identify that the changes in FGI's governance structure compared to FGPC's supported the trust repair process and improved the fund's overall performance.

\section{Operational Results}

The aim of this subsection is to present the operational data of the FGI and compare them with similar operations or the international benchmark when applicable.

The percentage of financing with FGI guarantees in relation to the total number of eligible operations up to December of 2016 is 5.5\%. Despite this, it passes the $10 \%$ mark in seven banks and $50 \%$ of the operations in another two. The rate of applications is $3.10 \%$ (December 2016), which is lower than the default rate of the financial system, which was $8 \%$ for the same period (BCB, 2017).

The new borrower results (Table 6) confirms the interviewees' perception regarding wider access to credit. Almost $50 \%$ of the borrowers had never accessed BNDES credit, more than double the average operations without guarantee during the same period, which is confirms FGI financial additionality, in accordance with Jonsson (2009). 
Building Trust in a Guarantee Fund in a Challenging Institutional Environment

Table 6 - Financial Additionality - New borrowers

\begin{tabular}{|c|c|c|c|c|c|c|c|c|}
\cline { 2 - 8 } \multicolumn{1}{c|}{} & \multicolumn{4}{c|}{ Without Guarantee } & \multicolumn{4}{c|}{ With Guarantee } \\
\hline $\begin{array}{c}\text { New } \\
\text { borrower }\end{array}$ & $\begin{array}{c}\text { Value R\$ } \\
\text { Millions }\end{array}$ & $\begin{array}{c}\text { Value } \\
(\boldsymbol{\%})\end{array}$ & $\begin{array}{c}\mathbf{N}^{\mathbf{0}} \text { OPE } \\
(\#)\end{array}$ & $\begin{array}{c}\mathbf{N}^{\mathbf{0}} \text { OPE } \\
(\boldsymbol{\%})\end{array}$ & $\begin{array}{c}\text { Value R\$ } \\
\text { Millions }\end{array}$ & $\begin{array}{c}\text { Value } \\
(\boldsymbol{\%})\end{array}$ & $\begin{array}{c}\mathbf{N}^{\mathbf{0}} \text { OPE } \\
(\#)\end{array}$ & $\begin{array}{c}\mathbf{N}^{\mathbf{0}} \mathbf{\text { OPE }} \\
(\boldsymbol{\%})\end{array}$ \\
\hline No & 96.782 & $83,1 \%$ & 442.968 & $79,4 \%$ & 3.205 & $55,8 \%$ & 15.667 & $50,1 \%$ \\
Yes & 19.745 & $16,9 \%$ & 115.171 & $20,6 \%$ & 2.543 & $44,2 \%$ & 15.589 & $49,9 \%$ \\
Total & $\mathbf{1 1 6 . 5 2 7}$ & $\mathbf{1 0 0 , 0 \%}$ & $\mathbf{5 5 8 . 1 3 9}$ & $\mathbf{1 0 0 , 0 \%}$ & $\mathbf{5 . 7 4 8}$ & $\mathbf{1 0 0 , 0 \%}$ & $\mathbf{3 1 . 2 5 6}$ & $\mathbf{1 0 0 , 0 \%}$ \\
\hline
\end{tabular}

Source: BNDES. Operations up to 31/12/2016.

The operations risk comparison shows that the fund enables SMEs with greater risk to access BNDES' credit, as showed by Table 7 . This credit has the lowest rates on the market for this segment. Risk $\mathrm{C}$ represents $39.6 \%$ of FGI operations, which is almost double the operations without guarantee, in which only $21.4 \%$ are risk level $\mathrm{C}$ or lower. The indicator shows that companies enjoy better credit access conditions, in accordance with the expectations of Jonsson (2009).

Table 7 - Risk attributed by the financial agent

\begin{tabular}{|c|c|c|c|c|c|c|}
\cline { 2 - 7 } \multicolumn{1}{c|}{} & \multicolumn{2}{c|}{ Without Guarantee } & \multicolumn{4}{c|}{ With Guarantee } \\
\hline Risk $^{\mathbf{1}}$ & Value (\%) & $\mathbf{N}^{\mathbf{0}}$ OPE (\%) & $\begin{array}{c}\text { Value R\$ } \\
\text { Millions }\end{array}$ & Value (\%) & $\mathbf{N}^{\mathbf{0}}$ OPE (\#) & $\mathbf{N}^{\mathbf{0}}$ OPE (\%) \\
\hline AA & $47,3 \%$ & $28,4 \%$ & 1.062 & $18,5 \%$ & 5.375 & $17,2 \%$ \\
A & $20,9 \%$ & $20,8 \%$ & 1.296 & $22,6 \%$ & 7.095 & $22,7 \%$ \\
B & $22,2 \%$ & $29,4 \%$ & 1.341 & $23,3 \%$ & 6.408 & $20,5 \%$ \\
C & $4,0 \%$ & $12,7 \%$ & 2.048 & $35,6 \%$ & 12.378 & $39,6 \%$ \\
D-H & $5,6 \%$ & $8,7 \%$ & & & & \\
Total & $\mathbf{1 0 0 , 0 \%}$ & $\mathbf{1 0 0 , 0 \%}$ & $\mathbf{5 . 7 4 8}$ & $\mathbf{1 0 0 , 0 \%}$ & $\mathbf{3 1 . 2 5 6}$ & $\mathbf{1 0 0 , 0 \%}$ \\
\hline
\end{tabular}

Source: BNDES - Operations up to 31/12/2016. Resolution 2682/99 (BCB)

The FGI guarantees operations in all Brazilian states, as showed by the map in Figure 1 (the distribution of operations by municipality). The fund has a larger share in the North and Northeast than the other operations of the BNDES. This demonstrates the economic and social additionality of the FGI, as these are the least developed states in Brazil. 
Building Trust in a Guarantee Fund in a Challenging Institutional Environment

Figure 1 - Distribution of Operations by Municipality

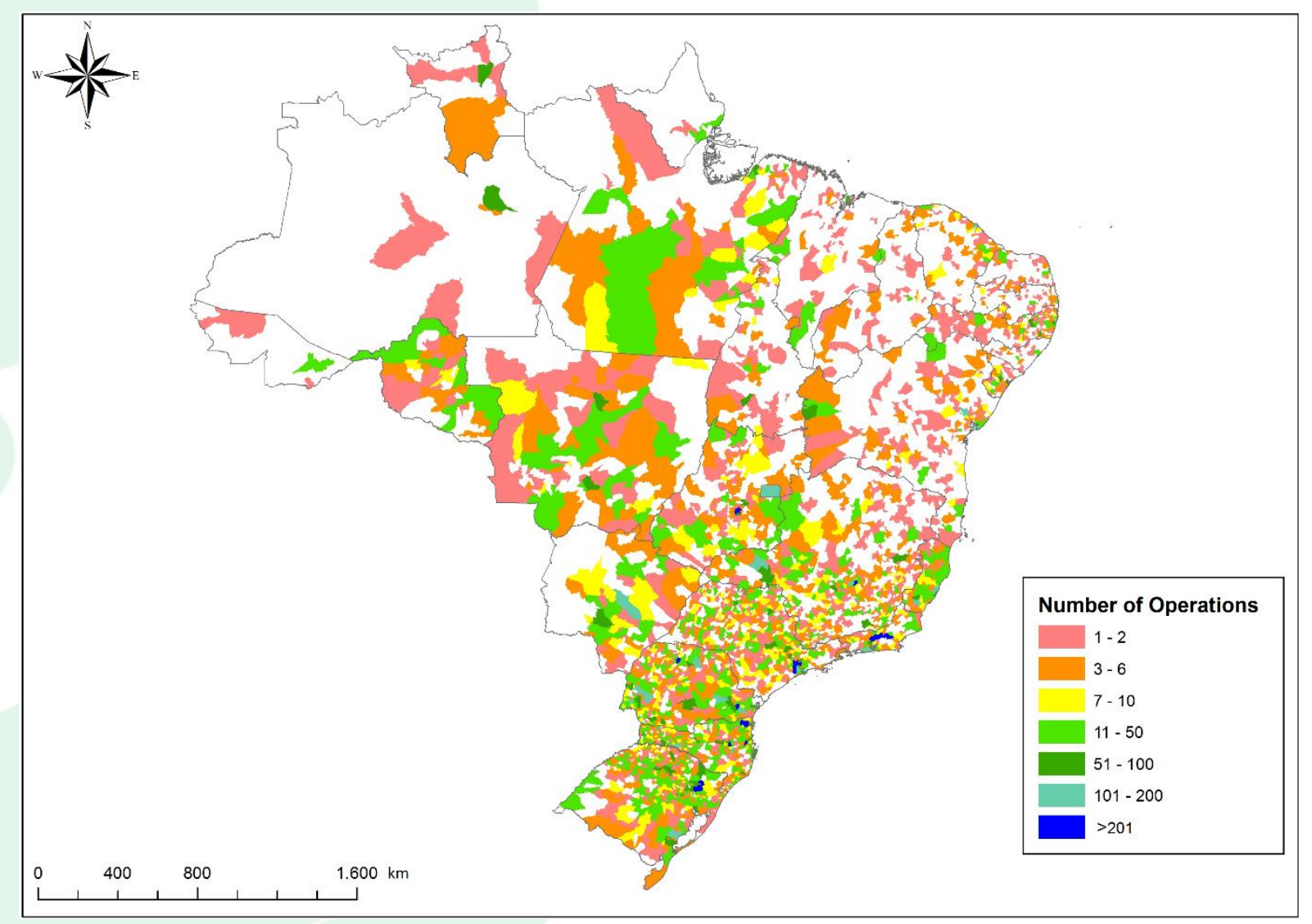

Source: BNDES. Operations engaged up to 31/12/2016.

Operations with FGI have higher average values for all companies' size analyzed, (Microentreprenuers, microenterprises, small and medium-sized enterprises), which is consistent with financial additionality effect, as showed by the graph in Figure 2. The medium average guarantee percentage diminishes according to the size of the company, since smaller companies have more difficulties to provide collateral to the banks.

Figure 2 - Average financed value by firm size with and without FGI coverage

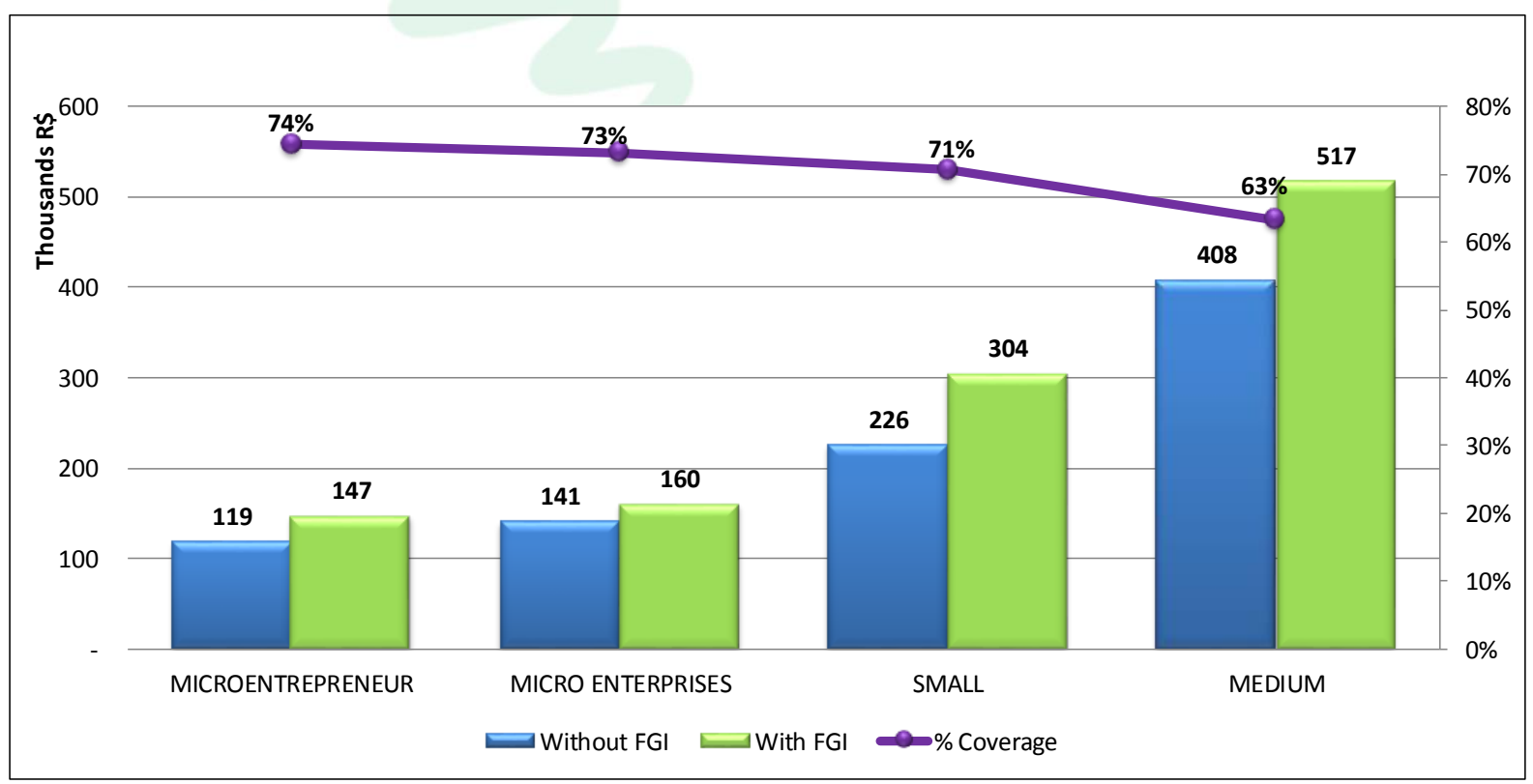

Source: BNDES. Operations up to 31/12/2016. 
Operations with FGI have higher term for two firm sizes, micro and medium, showing a mixed result, that does not fully confirm the expected results, as showed by Figure 3 .

Figure 3 - Average term (in months) by firm size with and without FGI coverage

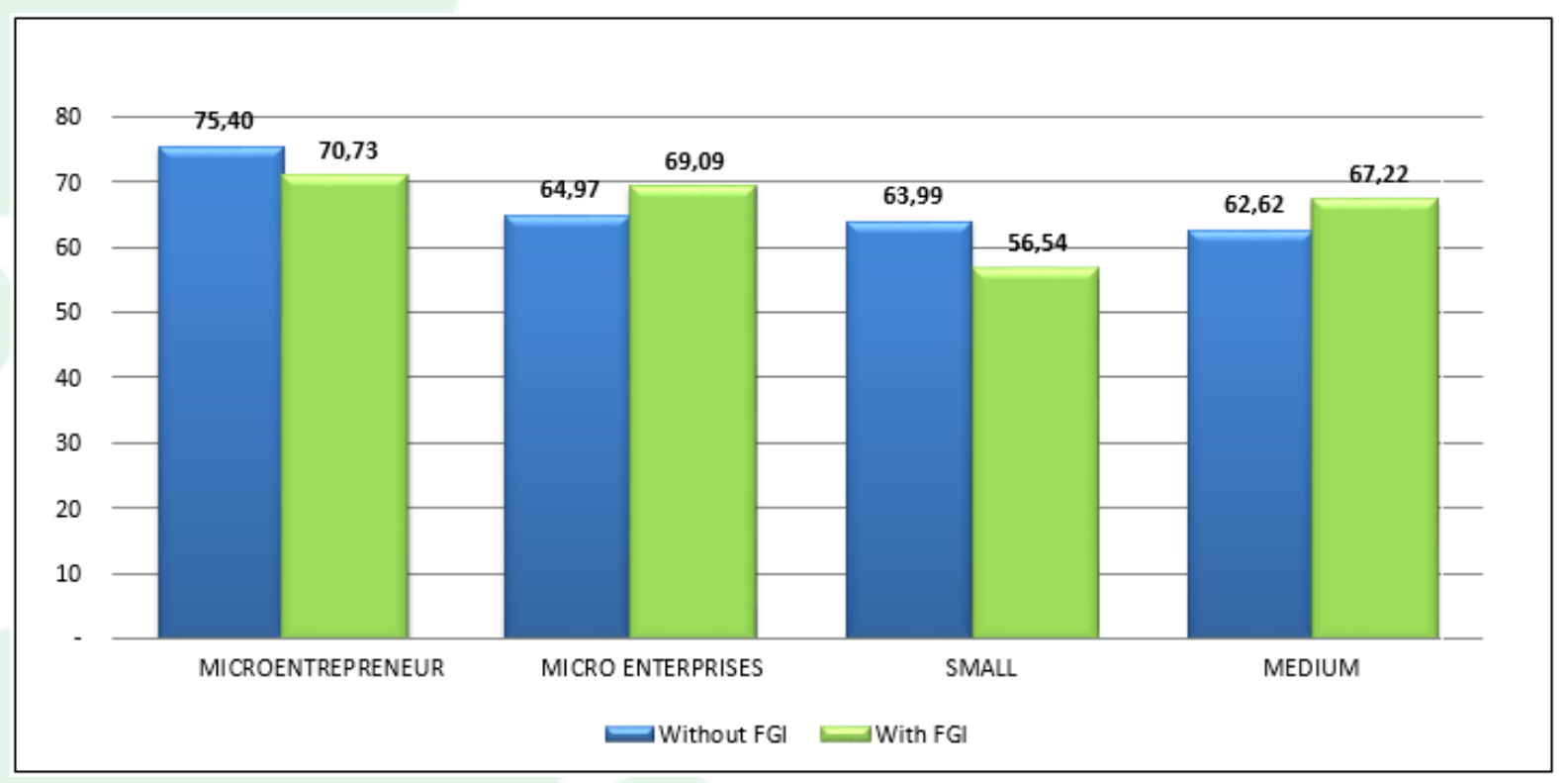

Source: BNDES. Operations up to 31/12/2016.

The results indicated that the FGI is fulfilling its mission to provide credit access to MSMEs. However, further analysis is need to isolate other possible effects and assure that the results are statically consistent. Other techniques besides descriptive statistics should be employed, like Propensity score matching, Regression discontinuity, Natural and quasi-natural experiment or Randomized experiment.

\section{DISCUSSION OF RESULTS AND FINAL CONSIDERATIONS}

The article analyzed the process of building trust in a guarantee fund - the FGI in a challenging institutional environment. Lack of credit access can be related to at least three pillars of the Global Competitiveness Index were Brazil does not perform well: Institutions, Macroeconomic Environment and Financial market development. Therefore, the process had to take this environment into account and involved repairing trust in its relationship with banks, which had been shaken by the failure of a previous initiative involving the FGPC. The analysis focused on comparing FGI with CGS for microentrepreneurs and SMEs around the world and tried to identify best practices, suitable governance structures and evaluate its effects on credit access and financial, economic and social additionality. The analysis of the interviews revealed that managers were committed to building a relationship of trust with the banks, with the BNDES's previous experience providing some interesting elements to help avoid repeating mistakes.

The use of BNDES, a NDB to manage the guarantee fund is also consistent with international practices and its role in developing financial markets and promote long term investment. The fund was structured as a private entity. The governance structure including the financial agents seeks to align interests, as proposed by Handley and Benton (2013). The fund pay claims on first demand and credit recovery is delegated to financial agents. These measures are due to the long term required by the Brazilian judicial system to recover credits, identified by WEF GDI and mentioned on the interviews.

The results showed that to build and repair trust and obtain a better performance it is necessary to find a balance between structural safety mechanisms that limit untrustworthy behavior, as analyzed by Gillespie and Dietz (2009) and Faems et al. (2008), using the mechanisms suggested by Boehs and Segatto-Mendes (2007), and a relational approach which reinforces trustworthy and predictable behavior (Lewicki and Bunker 1995). The latter uses non-binding contracts, as proposed by Malhotra and Murnighan (2002) and establishes information communication and exchange mechanisms (Gulati, Sytch 2007; Becerra, Gupta 2003) and joint work on tasks, while restricting conflicts to 
business-related issues (Mesquita, 2007; Tomlinson, Mayer, 2009), in a long-term perspective with common objectives that reinforce inter-organizational trust. These perspectives are complementary and can contribute to the success of inter-organizational alliances, in which collaboration - as put forward by Sundarämurthy and Lewis (2003) - prevails.

The operational results analysis showed that FGI promote credit access (almost $50 \%$ of the beneficiaries were new borrowers), regional deconcentration (North and Northeast have a greater share compared to loans without guarantee), accept more riskier takers, have financial additionality (higher values and more term to pay) and significant participation in eligible operations.

Furthermore, the fund monitored and identified the main benefits for the parties involved, including the guarantor, the banks and the beneficiaries, using these in their communications to make their use more widespread.

Some recommendations for future studies include extending the study to include other guarantee mechanisms, such as mutual credit guarantee associations and guarantee funds for other risks, in addition to credit risks, such as performance, engineering and failure to comply with contractual obligations.

The trust building and repair process can be applied to other types of inter-organizational relationships, such as those between suppliers and buyers, joint ventures and capital and contractual alliances, seeking to use an appropriate mix of structural and relational governance mechanisms.

\section{REFERENCES}

AECM, Association of European Guarantee Institutions. (2017) Retrieved from $<$ http://www.aecn.eu>.

BCB, Banco Central do Brasil, (2017). "Nota para a Imprensa - 26.4.2017". Política Monetária e Operações de Crédito do Sistema Financeiro. Brasília.

Beck, T.; De La Torre, A. (2007). "The basic analytics of access to financial services." Financial markets, institutions \& instruments, 16, no. 2 : 79-117.

Beck, T.; Demirgüc-Kunt, A.; Peria. M. S. M. (2008). "Bank financing for SMEs around the world: Drivers, obstacles, business models, and lending practices." World Bank Mimeo.

Beck, T.; Klapper, L. F.; Mendoza, J. C. (2010). “The typology of partial credit guarantee funds around the world". Journal of Financial Stability, 6, 10-25.
Becerra, M.; Gupta, A.K. (2003). Perceived Trustworthiness within the Organization: The Moderating Impact of Communication Frequency on Trustor and Trustee Effects. Organization Science, 14 (1):32-44.

Bndes, (2017). FGI- Fundo Garantidor para Investimentos. Rio de Janeiro. Retrieved from <http://www.bndes.gov.br/SiteBNDES/bndes/bndes _pt/Institucional/Apoio_Financeiro/Programas_e_F undos/FGI/index.html> [Accessed: 16 June 2017].

BNDES. (2016) "FGPC - Fundo de Aval". Rio de Janeiro. Retrieved from http://www.bndes.gov.br/SiteBNDES/bndes/bndes_ pt/Institucional/Instituicao_Financeira_Credenciada /FGPC/index.html.

Boehs, C. G. E.; Segatto-Mendes, A. P. (2007). Identificação de Mecanismo de Controle em alianças Estratégicas para Desenvolvimento Tecnológico: um Estudo Múltiplo de Casos no Setor Metal-mecânico ao longo das Fases de Relacionamento. Revista de Administração Contemporânea, 11 (3): 199-221.

BPIFRANCE. Banque Publique d'Investissement. (2017). Retrieved from <http://www.fogape.cl>.

Chieza, R. A. Ambros, J. O. (2006). “A importância do Crédito na visão Schumpeteriana e a experiência gaúcha na busca de alternativas à ampliação do acesso ao crédito para empresas de menor porte". III Encontro de Economia Gaúcha. Porto Alegre. Retrieved from <http://www.fee.tche.br/3eeg/Artigos/m09t03.pdf $>$.

Creswell, J. W. (2013). "Research design: Qualitative, quantitative, and mixed methods approaches". Sage publications.

Faems, D.; Janssens, M.; Madhok, A.; Van Looy, B. (2008). Toward an Integrative Perspective on Alliance governance: Connecting Contract Design, Trust Dynamics, and Contract Application. Academy of Management Journal, 51(6):10531078.

FNG, (2017). $\quad$ Retrieved from <http://www.fng.gov.co>.

Fogape, (2017) Retrieved from <http://www.fogape.cl>.

Fogapyme, (2017) Retrieved from <http://www.presidencia.gob.ar/sitios-degobierno/planes-de-gobierno/2685>. 
Foro Iberoamericano de Sistemas de Garantia, (2016). Documents from XXI Foro IberoAmericano de Sistemas de Garantia. Chile. Retrieved from <http:// www.foroiberoamericano.redegarantias.com/ $>$.

Gillespie, N.; Dietz, G. (2009). Trust Repair after an Organization Level Failure, Academy of Management Review, 34 (1):127-145.

Green, A. (2007). "Credit Guarantee Schemes for Small Enterprises: An Effective instrument to promote private sector-led growth?", SME Techinical Working Paper Series, UNIDO.

Gulati, R.; Sytch, M. (2007). Dependence Asymmetry and Joint Dependence in Interorganizational Relationships: Effects of Embeddedness on a Manufacturer's Performance in Procurement Relationships, Administrative Science Quarterly, 52: 32-69.

Handley, S. M.; Benton, W. C., Jr. (2013). The Influence Of Task And Location-Specific complexity on the control and coordination costs in global outsourcing relationships. Journal of Operations Management, n. 31, p. 109-128.

Honohan, P. (2010). "Partial credit guarantees: Principles and practice". Journal of Financial Stability. v. 6. p. 1-9.

Jonsson, M. (2010). "Performance of credit guarantee schemes (CGS)". HD Graduate Diploma in Finance. Copenhagen Business Scholl. Paper, (24).

Lall, S. (2001). "Competitiveness indices and developing countries: an economic evaluation of the global competitiveness report." World development 29, no. $9: 1501-1525$.

Lanz, L. Q. (2014). "Confiança e Controles em Relacionamentos Interorganizacionais: Um modelo de suas interações e de seus reflexos no desempenho", Doctoral Thesis, PUC-Rio. (2014).

Lanz, L. Q.; Tomei, P. A. (2013). "Aprendizagem Organizacional, Mudança Estratégica e Cultural: O caso do Fundo Garantidor para investimentos (FGI)". Gestão \& Conhecimento, 7(2), jul./dez., 153-180.

Lanz, L. Q.; Tomei, P. A. (2015). "Greater Access to Credit for Small and Micro Enterprises: Building trust in a Guarantee Fund". In: Congresso do Consejo Latinoamericano de Escuelas de Administración CLADEA (2015), Vina del Mar. Retrieved from http://faceauv.cl/cladea2015/images/stories/track5/ CLADEA_2015_submission_121_2_.pdf
Lanz, L. Q.; Tomei, P. A. (2014). "Confiança versus controle: análise da governança do Fundo Garantidor para Investimentos." Revista de Eletrônica de Estratégia e Negócios. v. 7, n.1,. jan./apr., pp. 105-136.

Lanz, L. Q.; Tomei, P. A. (2016). Building of InterOrganizational Trust in Challenging Contexts: The Case of the Investment Guarantee Fund International Journal of Knowledge, Culture, and Change Management: Annual Review, Volume 15, 2016,

Lanz, L. Q.; Perufo, J. V. (2013). "Risco de crédito e estimativa de alavancagem de um fundo de aval." Revista do BNDES. BNDES. Rio de Janeiro. n. 40. Dec., pp. 194-230.

Lewicki, R. J.; Bunker. B. B. (1995). Trust in Relationships: A Model of Development and Decline. In: Bunker. B. B.; Rubin, J. Z. (1995). Conflict, Cooperation, and Justice: Essays inspired by the work of Morton Deutsch, San Francisco: Jossey-Bass: 133-173.

Lopes, S. S.; Lagoa, J. C. D. S., Jr.; Cardoso, M. P., Piccinini, M. S. (2007). Fundos de garantia e acesso ao crédito das micro, pequenas e médias empresas. A experiência do FGPC: sucesso ou fracasso? BNDES Setorial, Rio de Janeiro, (26): 3-23.

Malhotra, D.; Murnighan, J. K. (2002). The Effects of Contracts on Interpersonal Trust. Administrative Science Quarterly, 47 (3): 534-559.

Mayer, R. C.; Davis, J. H.; Schoorman, F. D. (1995). An Integrative Model of Organizational Trust. The Academy of Management Review, Vol. 20, No. 3, Jul., p. 709-734.

Mercedes, D.; Ketels, C.; Porter, M. E.; Stern, S. (2012). "The Determinants of National Competitiveness". National Bureau of Economic Research: Working Paper 18249.

Mesquita, L. F. (2007). Starting Over When The Bickering Never Ends: Rebuilding Aggregate Trust Among Clustered Firms Through Trust Facilitators. Academy of Management Review, 32(1):72-91.

NAFIN, National Financiera S. A. (2017), Retrieved from $\langle$ http://www.nafin.com>.

OECD. Organization For Economic Co-Operation And Development. (2010). "Facilitating access to Finance: Discussion Paper on Credit Guarantee 
Schemes." $\quad$ Retrieved from www.oecd.org/daf/psd/45324327.pdf>.

Pombo, P. G. (2006). “Aportes Conceptuales y características para una clasificación internacional de los sistemas/esquemas de garantía”. Doctoral Thesis. Universidad de Córdoba.

Pombo, P. G.; Herrero, A. (2003). Los sistemas de garantia para micro y la pyme em uma conomia globalizada. DP Editorial. Sevilla.

Torres, E.; Zeidan, R. (2016). "The life-cycle of national development banks: The experience of Brazil's BNDES." The Quarterly Review of Economics and Finance 62 : 97-104.

Saadani, Y., Arvai, Z.; Rocha, R. D. R. (2011) “A review of credit guarantee schemes in the Middle East and North Africa Region". World Bank Policy Research Working Paper Series.

Schwab, K., Sala-i-Martin, X. (2017). "The global competitiveness report 2016-2017." Geneva: World Economic Forum.

Sebrae. Serviço Brasileiro de Apoio à Micro e Pequena Empresa. (2016). Sobrevivência das Empresas no Brasil. Coleção Estudos e Pesquisas. Brasília: Sebrae.

Sebrae, (2017). Pequenos Negócios no Brasil. Boletim Estudos e Pesquisas; n. 57 April. Brasília; Sebrae.

Sebrae; Fubra. Fundação Universitária de Brasília. (2004). Fatores condicionantes e taxa de mortalidade de empresas no Brasil. Brasília: Sebrae e Fubra.

Studart, R.; Gallagher, K. P. (2016). "Infrastructure for Sustainable Development: The Role of National Development Banks" Global Economic Governance Initiative. GEGI Policy Brief 007• 10 .

Sundarämurthy, C.; Lewis, M. (2003). Control and Collaboration: Paradoxes of Governance. Academy of Management Review. 28(3):397-415.

Das, T. K.; Teng, B. S. (2001). Trust, Control and Risk in Strategic Alliances: An Integrated Framework. Organization Studies. V. 22(2): 251-83.

Tomlinson, E. C.; Mayer, R. C. (2009). The Role of Causal Attribution Dimensions in Trust Repair. Academy of Management Review, 34(1):85-104.

Zaheer, A., Mcevily, B.; Perrone, V. (1998). Does Trust Matter? Exploring the Effects of Interorganizational and Interpersonal Trust on Performance. Organization Science, 9(2):141-159.

Zica, R. M. F.; Martins, H. C. (2008). "Sistema de garantia de crédito para micro e pequenas empresas no Brasil: proposta de um modelo." Revista de Administração Pública 42, no. 1: 181-204.

World Bank. (2015). "Doing Business 2015: Going Beyond Efficiency. Economy Profile: Brazil", pp. 4-28.

Yin, R. K. (2013). Case study research: Design and methods. Sage Publications. 